\title{
EPHA8 Gene
}

National Cancer Institute

\section{Source}

National Cancer Institute. EPHA8 Gene. NCI Thesaurus. Code C24365.

This gene plays a role in axonal interactions in the nervous system. 